\title{
Study on Germination of Seven Barley Cultivars (Hordeum vulgare L.) under Salt Stress
}

\author{
Najoua Abdi ${ }^{1,3}$, Salma Wasti ${ }^{2}$, Moncef Ben Salem ${ }^{1}$, Mouldi El Faleh ${ }^{4}$ \& Elhem Mallek-Maalej ${ }^{1,3}$ \\ ${ }^{1}$ Laboratory of Biotechnology Applied to Agriculture (LB2A), National Agronomic Research Institute of Tunisia \\ (INRAT), Ariana, Tunisia \\ ${ }^{2}$ Laboratory of Plant Ecology, Department of Biology, Faculty of Sciences of Tunis, University Tunis El Manar, \\ Tunis, Tunisia \\ ${ }^{3}$ Science Faculty of Bizerte (F.S.B.), Jarzouna, Tunisia \\ ${ }^{4}$ Field Crop Laboratory, National Agronomic Research Institute of Tunisia (INRAT), Ariana, Tunisia \\ Correspondence: Najoua Abdi, Laboratory of Biotechnology Applied to Agriculture (LB2A), National \\ Agronomic Research Institute of Tunisia (INRAT), Hédi Karray Street, 2049 Ariana, Tunisia. E-mail: \\ abdinajoua@yahoo.fr
}

Received: May 16, 2016

Accepted: June 16, $2016 \quad$ Online Published: July 15, 2016

doi:10.5539/jas.v8n8p88

URL: http://dx.doi.org/10.5539/jas.v8n8p88

\begin{abstract}
The present work aims to study the germination behavior of seven Tunisian varieties of barley (Kounouz, Faiz, Roho, Manel, Lemsi, Rihane and Tej) during germination without or with $\mathrm{NaCl}$. These varieties have been chosen in order to have the greatest possible diversity on the agro-physiologic level and to select tolerant plants to salinity. Barley grains are germinated (in Petri dishes lined with a double layer of filter paper soaked) in a solution of $\mathrm{NaCl} 0,50,100,150,200 \mathrm{mM}$ for 7days. Two germination criteria were studied: the radicle breaching and the coleoptile's emergence. The measured parameters were the kinetics, the germination rate, the final germination and the GSI (Germination Stress Index). The results showed that, daily germination decreased significantly under $\mathrm{NaCl}$. If we consider the two germination criteria, salt exerts a depressive effect on seed germination capacity of barley and slows germination speed. There is also an important intra-specific variability opposite of salinity. The studied barley varieties were classified in descending order of salt tolerance as following: Roho $>$ Faiz $>$ Kounouz $>$ Manel $>$ Rihane $>$ Lemsi $>$ Tej.
\end{abstract}

Keywords: barley, $\mathrm{NaCl}$, germination, salt tolerance

\section{Introduction}

The cereals yield, especially barley (Hordeum vulgare L.), remains moderate and heavily influenced by biotic and abiotic stresses (Slama et al., 2005). Salinity is a major abiotic stress, some 800 million hectares of land are affected by high levels of salt in the world (Munns, 2005). In Tunisia, saline soils occupy about $23 \%$ of the total area with 8.7 million hectares of arable land (FAO, 2008). However, water resources for irrigation in Tunisia are limited and of poor quality, 30\% of these resources have a salt content greater than $3 \mathrm{~g} / \mathrm{L}$ (Cheikh et al., 2008). For cereals, the depressive effect of salt occurs from a critical threshold concentration characteristic of the species or variety (Bouaouina et al., 2000). The plant species response to salt depends on the species itself, its variety, the culture salt concentration and the stage of plant development (Mallek-Maalej et al., 2004). Seed germination is the most critical phase of the plant life, it is a physiological phase which corresponds to the transition from the dormant seeds phase to a reactivation phase of the metabolism (Gallardo et al., 2003). Germination and plant seedling were considered as salt sensitive stages (Munns \& Tester, 2008). Indeed, salinity reduces speed germination and exposes seeds to some growth risk (Slama, 2004). The high salt concentrations in the medium affect seriously the seed germination by reducing the bioavailability of water retained by $\mathrm{Na}^{+}$ions causing water deficit (Parida \& Das, 2005), which disrupts the absorption of water by seeds leading to a delay in germination process (Jamil et al., 2006). At this osmotic component is added an ionic component characterized by an excess of $\mathrm{Na}^{+}, \mathrm{Cl}^{-}, \mathrm{K}^{+}$levels and $\mathrm{Ca}^{2+}$ deficiency (Karimi et al., 2005). Furthermore, salinity caused a disruption of the enzyme systems involved in various physiological functions of the seed; such as decreased activity of polyphenol-oxidases and amylases (Khemiri et al., 2004). Rajaskaran et al. (2000) suggest that 
tolerance at germination stage is not expressed in the adult stage in several species such as maize and beans. Indeed, salt tolerance at germination stage may be similar or different from that in the adult plant stage. For some species, the seeds that have an ability to germinate under salinity conditions have susceptibility to continue this stress tolerance, during their subsequent growth (Rozema, 1975).

Thus, the identification of salt tolerant cultivars would certainly improve the production zones exposed to salinity risk or irrigated with brackish water and present a high interest in the varietal improvement (Slama, 1996).

The objective of this work was to use a precocity and reliable test to characterize the effect of salt stress on seven Tunisian barley cultivars at the germination stage and to identify the most resistant one. This study would highlight the salinity influence on different characteristic parameters such as germination rate, kinetics and the germination stress tolerance index to identify the degree of salinity tolerance.

\section{Materials and Methods}

\subsection{Plant Material}

Seven cultivars of barley were used in this study. Origin and varieties characteristics are shown in Table 1.

Table 1. Origin and characteristics of the studied cultivars (Deghais et al., 2007)

\begin{tabular}{|c|c|c|c|}
\hline Varieties & Cross and/or Pedigree & Origin & Characteristics \\
\hline Roho & Roho & Introduced from Denmark in 1975 & $\begin{array}{l}\text { Adapted to low rainfall and } \\
\text { semi-arid regions }\end{array}$ \\
\hline Faiz & earely Russian/Apam & Introduced from ICARDA in 1979 & Adapted to semi-arid regions \\
\hline Manel & $\begin{array}{l}\text { L527/5/As54/Tra//2*Cer/TolI/3/Avt/TolI//Bz/4/Vt/Pro// } \\
\text { TolI ICB81-607-1Kf-1Bj-12Bj-11Bj-1Bj-1Bj-0Bj }\end{array}$ & Selected by INRAT in 1996 & Suitable for wetlands \\
\hline Lemsi & Rapidan & Selected by INRAT in 2009 & Used as fodder \\
\hline Tej & WI2198 & Introduced from Australia in 1975 & Adapted to low rainfall regions \\
\hline Rihane-03 & Atlas 46/Arrivat//Athenais ICB-2L-1AP-3AP-0AP-0Kf & Introduced from ICARDA in 1982 & Adapted to semi-arid regions \\
\hline Kounouz & ICB95-0508-0AP-1BJ-2BJ-0BJ & Selected by INRAT in 2011 & Resistance to fungal diseases \\
\hline
\end{tabular}

\subsection{Germination Experiment}

Barley seeds were surface-sterilized by soaking in $10 \%$ sodium hypochlorite solution for 15 min followed by three washes with sterile distilled water. Seeds were then germinated in $9 \mathrm{~cm}$ Petri dishes on filter paper discs moistened with distilled water (control) or $\mathrm{NaCl}$ solutions, with 20 seeds in each dish and were incubated in darkness at $25^{\circ} \mathrm{C}$ for 7 days.

The experimental design adopted was a randomized block with 3 replications, 7 varieties in both control $(\mathrm{NaCl} 0$ $\mathrm{mM})$ and stressed conditions ( $\mathrm{NaCl} 50,100,150$ and $200 \mathrm{mM}$ ).

The studied germination criteria were the radicle breaching and the coleoptile's emergence. The number of germinated grains was evaluated every 24 hours and germination rate was determined in the $7^{\text {th }}$ day.

\subsection{Measurements and Data Collection}

The final germination rate was calculated the $7^{\text {th }}$ day as corrected germination rate (GC) from the formula of Smith and Dobrenz (1987):

$$
\mathrm{GC} \%=(\mathrm{Nx} / \mathrm{No}) \times 100
$$

Where, $\mathrm{Nx}$ is the number of sprouts in a medium containing $\mathrm{x} \mathrm{mM} \mathrm{NaCl}$, and $\mathrm{No}$ the number of sprouts with $0 \mathrm{mM}$ $\mathrm{NaCl}$ (control).

$\mathrm{GC} \%$ is the best way to identify the salt concentration of physiological limit of the seed germination.

The germination speed which express the germination energy responsible for the exhaustion of the grain reserve was estimated by the mean time (T50) which corresponds to the germination of $50 \%$ of the total grains (Lang, 1965).

The germination kinetics was followed to evaluate germination behaviour of the studied varieties. 
The number of germinated grains was evaluated every 24 hours and the germination stress index (GSI) was calculated using the index the promptness index (PI) estimated by Ashraf et al. (2008).

$$
\begin{gathered}
\mathrm{GSI}=(\mathrm{PI} \text { of stressed seeds/PI of control seeds }) \times 100 \\
\mathrm{PI}=\mathrm{nd} 1(1.00)+\mathrm{nd} 2(0.75)+\mathrm{nd} 3(0.50)+\mathrm{nd} 4(0.25)
\end{gathered}
$$

Where, nd1, nd2, nd 3 and nd $4=$ number of seeds germinated respectively on the $4^{\text {st }}, 5^{\text {nd }}, 6^{\text {rd }}$ and $7^{\text {th }}$ day.

\subsection{Statistical Analysis}

The statistical analysis was performed with the "Statistica" software (version 6.0). Mean values and standard error (SE) were obtained from at least 3 replicates for germination parameters. A $P$ value $\leq 0.05$ was considered to be statistically significant; using Duncan's multiple range test.

\section{Results}

\subsection{Germination Rate}

Figures 1 and 2 show the effect of different $\mathrm{NaCl}$ concentrations of the seven studied barley cultivars germination at radicle breaching and coleoptile's emergence stages, respectively. As evident, the highest percentage of germination was at $0 \mathrm{mM} \mathrm{NaCl}$ (control) for all studied cultivars (especially at coleoptile's emergence). As shown in Figure 2, the coleoptile's emergence after 7 days of germination seems to be more affected by salt stress than radicle breaching for all studied cultivars barley. For example, for Tej, salt treatment $200 \mathrm{mM} \mathrm{NaCl}$, reduced germination by $88 \%$ at coleoptile's emergence, in contrast reduction of only $50 \%$ at radicle breaching.

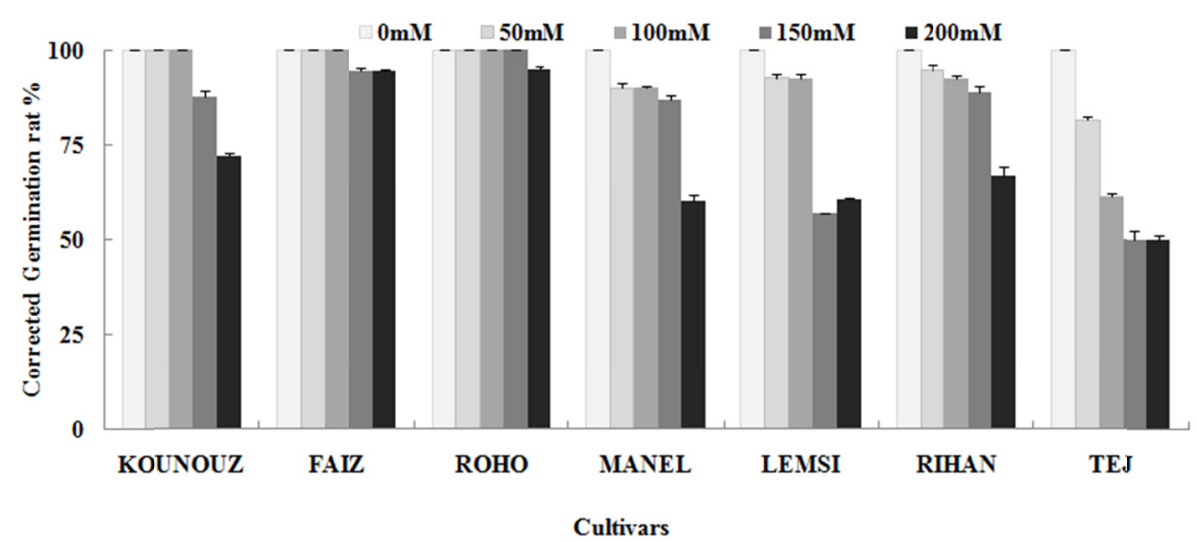

Figure 1. $\mathrm{NaCl}$ effect on corrected germination rate GC\% (radicle breaching) of different barley cultivars grains after 7 days of germination. Each value represents the mean of 3 replicates

Note. Bars indicate \pm standard error $(P \leq 0.05)$.

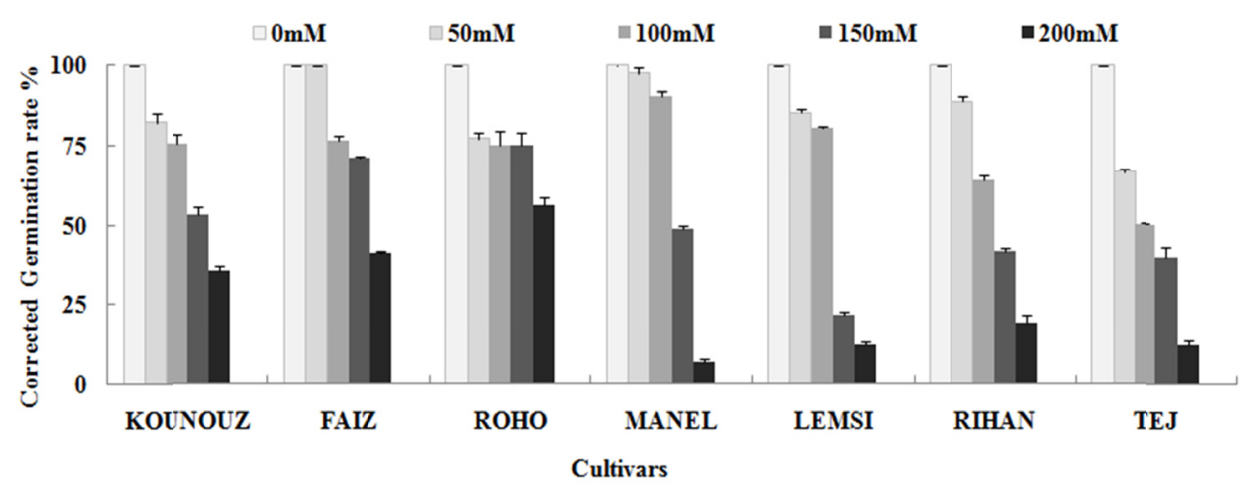

Figure 2. $\mathrm{NaCl}$ effect on corrected germination rate $\mathrm{GC} \%$ (coleoptile's emergence) of different barley varieties grains after 7 days of germination. Each value represents the mean of 3 replicates

Note. Bars indicate \pm standard error $(P \leq 0.05)$. 


\subsection{Kinetics of Germination}

Figures 3 and 4 show the kinetics evolution of germination under $\mathrm{NaCl}$ stress and control. In the various cases, the germination curves show a sigmoidal shape, with its three conventional phases: the latency, the linear phase reflecting a rapid increase in germination and finally the bearing corresponding to the final germination rate (germination capacity).

The latency phase duration was variable depending on $\mathrm{NaCl}$ concentration. In control conditions, it corresponds to two days for radicle reaching of the seven varieties (Figure 3A) and four days for the coleoptile's emergence (Figure 4A). With $200 \mathrm{mM} \mathrm{NaCl}$, the duration was 3 days for the radicle breaching of the seven cultivars grains (Figure 3B), whereas for coleoptile's emergence in Kounouz, Faiz and Manel it was 6 days and reaches more than 7 days for Tej, Rihane and Lemsi cultivars (Figure 4B).

In salt medium containing $50 \mathrm{mM} \mathrm{NaCl}$, germination of barley cultivars was unaffected and the recorded values were statistically close to the values obtained in the control. With $100 \mathrm{mM} \mathrm{NaCl}$, the percentage of germinated grains decreased and becomes weaker at $200 \mathrm{mM}$ concentration.
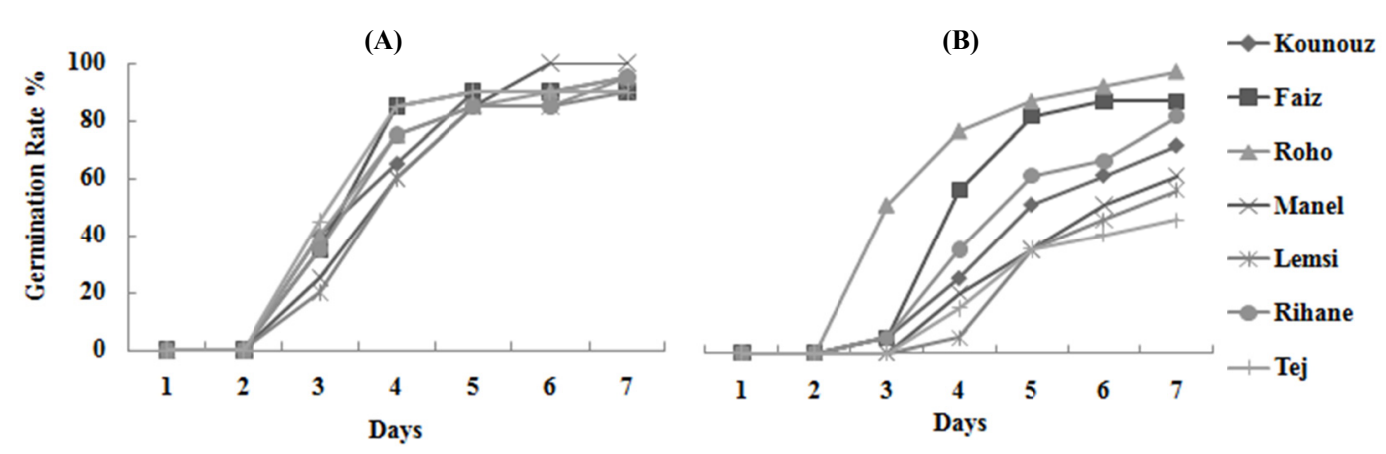

Figure 3. Evolution of the cumulative seed germination percentage of different barley cultivars (radicle breaching) in absence of salt (A) and at $200 \mathrm{mM} \mathrm{NaCl}$ (B)

Note. Each value represents the mean of three repetitions.

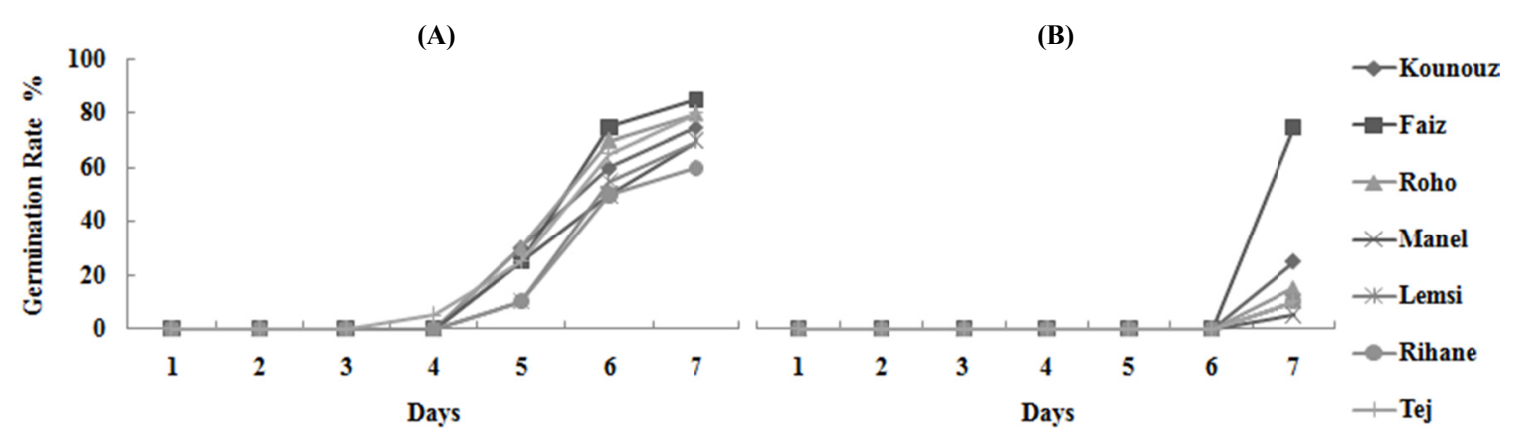

Figure 4. Evolution of the cumulative seed germination percentage of different barley cultivars (coleoptile's emergence) in absence of salt (A) and at $200 \mathrm{mM} \mathrm{NaCl}(\mathrm{B})$

Note. Each value represents the mean of three repetitions.

\subsection{Mean Germination Time (T50)}

The germination speed rate can be estimated by the average time (T50) corresponding to $50 \%$ of the seed lot germination. The Figure 5, which presents the values of T50 for each treatment, shows that in the absence of salt, radicle breaching speed is the same for all cultivars and it is faster for Roho cultivar at $200 \mathrm{mM} \mathrm{NaCl}$. As shown in Figures 5(A) and 5(B) for all cultivars, $\mathrm{NaCl}$ effect results in an increase of (T50), or in a decrease of the germination speed for plants exposed to low concentrations. In contrast, for $\mathrm{NaCl}$ concentrations up to $200 \mathrm{mM}$, 
the T50 increase significantly reaching more than 7 days in sensitive cultivars such as Lemsi and Tej for radicle breaching. While for coleoptile's emergence, the speed is slowed even with low concentrations of $\mathrm{NaCl}$ and was inhibited even at $100 \mathrm{mM}$ for Rihane cultivar.

(A)

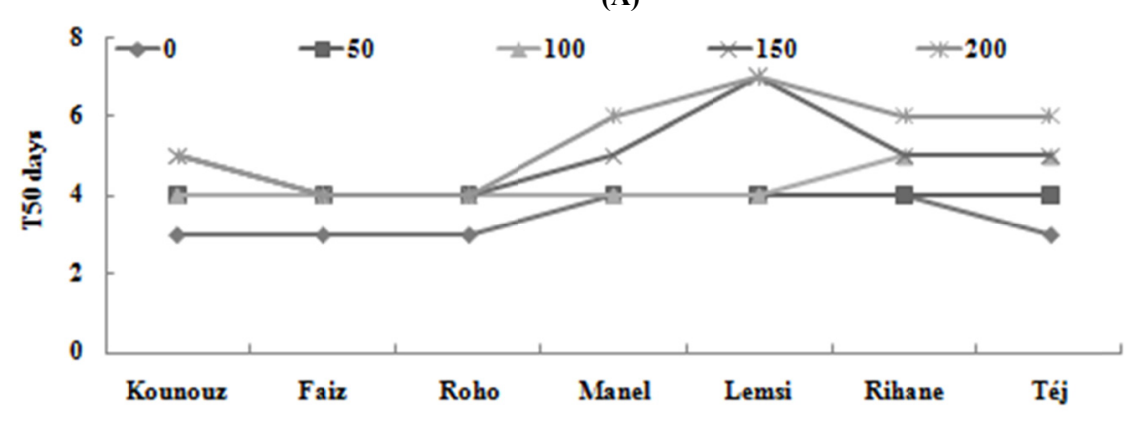

(B)

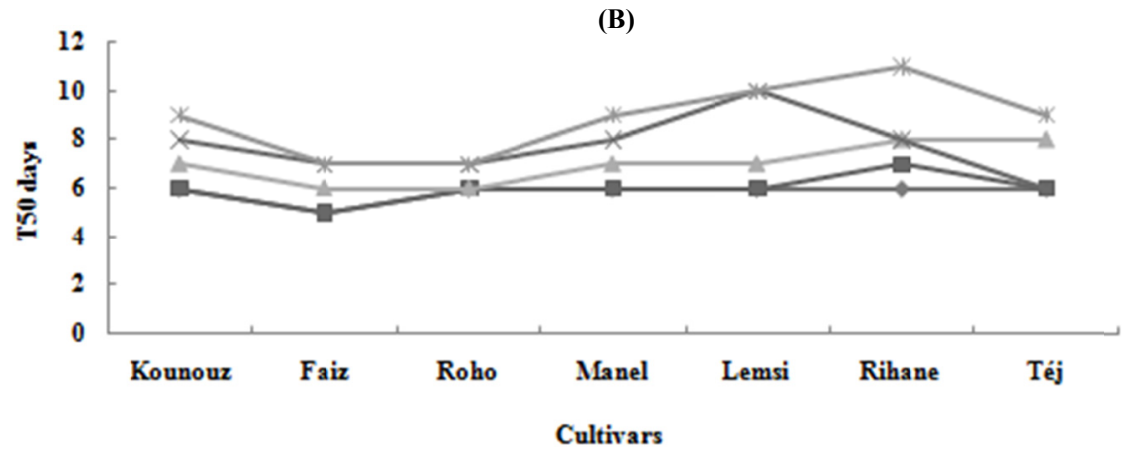

Figure 5. Effect of different $\mathrm{NaCl}$ concentrations (0 to $200 \mathrm{mM}$ ) on the mean germination time (T50) of barley grains cultivars (A) (radical emergence) and (B) (coleoptiles emergence)

Note. Each value represents the mean of three repetitions.

\subsection{Germination Stress Index}

Figures 6(A) and 6(B) show that after 7 days of germination, the highest germination index (GSI \%) under $\mathrm{NaCl}$ $0 \mathrm{mM}$ was observed for the 7 varieties. The radicle breaching with $200 \mathrm{mM} \mathrm{NaCl}$ is low for Manel, Lemsi, Rihane and Tej cultivars where the GSI reaches 39\%, 37\%, 36\% and 34\% respectively. Whereas for the other cultivars, it is rather important especially for Faiz and Roho where the GSI reaches $83 \%$ and $82 \%$ respectively, for Kounouz the GSI is 53\%. While for the coleoptile's emergence with $200 \mathrm{mM} \mathrm{NaCl}$, cultivars were divided in to 3 groups. The GSI is very low for Manel (2\%), Tej, Lemsi and Rihane; and it is very important for Faiz (56\%). Whereas, the GSI of Kounouz and Roho occupied an intermediate place. 
(A)

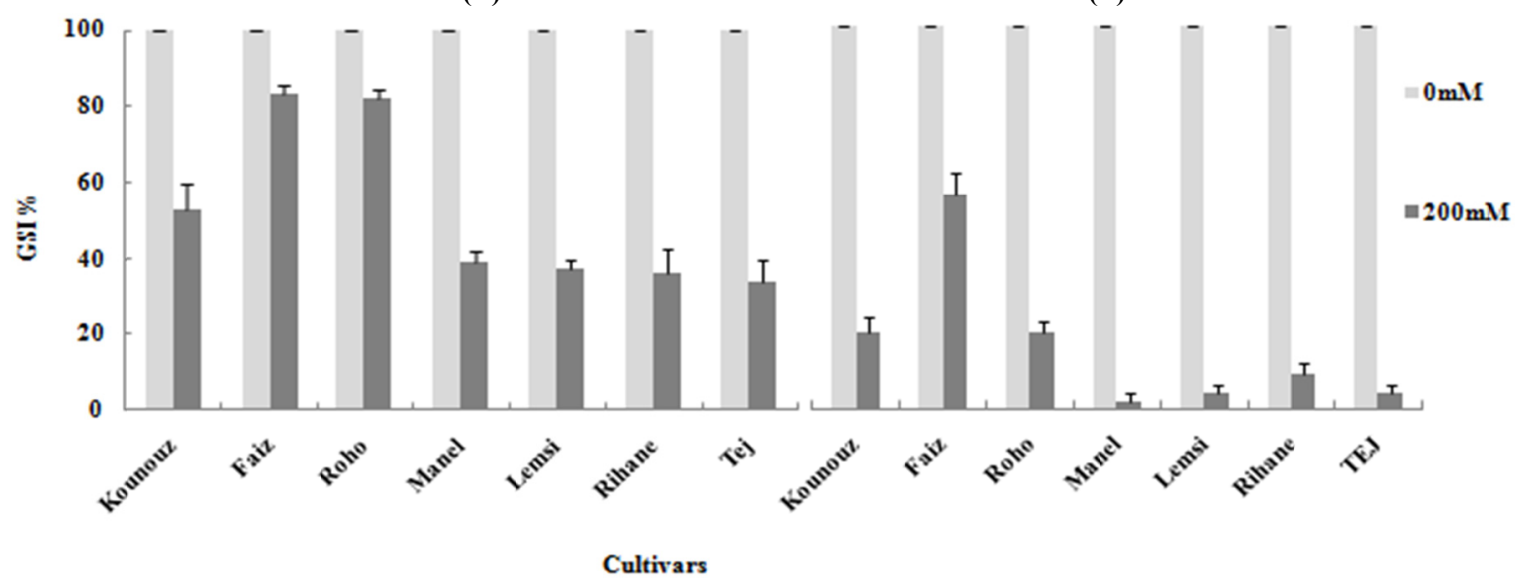

Figure 6. Germination stress index (GSI \%) of the seven Tunisian barley varieties at radicle breaching (A) and coleoptile's emergence (B)

Note. Each value represents the mean of 3 replicates. Bars indicate \pm standard error $(P \leq 0.05)$.

Table 2. Variance analysis of Corrected germination rate (GC\%), mean time (T50) and Germination Stress Index (GSI) at the radicle breaching stage

\begin{tabular}{|c|c|c|c|c|c|c|c|}
\hline \multirow{2}{*}{ Source of variation } & \multirow{2}{*}{ d.f } & \multicolumn{2}{|c|}{$\mathrm{GC} \%$} & \multicolumn{2}{|c|}{$\mathrm{T} 50$} & \multicolumn{2}{|c|}{ GSI } \\
\hline & & F. cal & $P$ & F. cal & $\mathrm{P}$ & F. cal & $\mathrm{P}$ \\
\hline Cultivars (Cultiv.) & 6 & 23.30 & $0.000 * * *$ & 4.88 & $0.000 * * *$ & 8.41 & $0.000 * * *$ \\
\hline Treatments (Treat.) & 4 & 35.13 & $0.000 * * *$ & 12.82 & $0.000 * * *$ & 32.17 & $0.000 * * *$ \\
\hline Cultiv. $\times$ Treat. & 24 & 3.13 & $0.000 * * *$ & 0.89 & $0.000 * * *$ & 4.68 & 0.000 *** \\
\hline
\end{tabular}

Note. ${ }^{*},{ }^{* *},{ }^{* * *}$ significant at $0.05,0.01$ and 0.001 levels, respectively.

Table 3. Variance analysis of Corrected germination rate (GC\%), mean time (T50) and Germination Stress Index (GSI) at the coleoptile's emergence stage

\begin{tabular}{|c|c|c|c|c|c|c|c|}
\hline \multirow{2}{*}{ Source of variation } & \multirow{2}{*}{ d.f } & \multicolumn{2}{|c|}{$\mathrm{GC} \%$} & \multicolumn{2}{|c|}{ T50 } & \multicolumn{2}{|c|}{ GSI } \\
\hline & & F. cal & $P$ & F. cal & $\mathrm{P}$ & F. cal & $P$ \\
\hline Cultivars (Cultiv.) & 6 & 4.42 & $0.000 * * *$ & 21.94 & $0.000 * * *$ & 1.13 & 0.360 \\
\hline Treatments (Treat.) & 4 & 53.45 & $0.000 * * *$ & 139.59 & $0.000 * * *$ & 55.24 & $0.000 * * *$ \\
\hline Cultiv. $\times$ Treat. & 24 & 1.17 & 0.300 & 9.87 & $0.000 * * *$ & 0.80 & 0.730 \\
\hline
\end{tabular}

Note. ${ }^{*}, * *, * *$ significant at $0.05,0.01$ and 0.001 levels, respectively.

\section{Discussion}

Plants display great diversity with regard to soil salinity tolerance. Species distribution and survival mainly depend on the seed ability to complete germination and the seedling ability to develop successfully under unfavorable conditions (Živkvic et al., 2007). The mechanism of inhibition of germination and seedling growth by $\mathrm{NaCl}$, may be related to radicle breaching due to insufficient water absorption, or may be ascribed to toxic effects on the embryo (Mazher et al., 2007).

Our preliminary results showed a depressive effect of salt on barley seed germination which is consistent with other studies (Yousofinia et al., 2012). Results show that, whatever the cultivar, the rate of seed germination under salt stress are reduced compared to control $(0 \mathrm{mM} \mathrm{NaCl})$ for all concentrations used. Those findings are in agreement with those of Jamil et al. (2006) who stated that salinity caused a significant reduction in germination percentage and germination rate. This study shows that all cultivars seeds germinated at moderate $\mathrm{NaCl}$ concentration $(100 \mathrm{mM})$, while at higher concentrations, the seeds germination were reduced for all cultivars. Indeed, Konouz, Faiz and Roho seeds had the greatest germination percentage at $200 \mathrm{mM} \mathrm{NaCl}(72,94,95 \%)$ 
respectively, while seeds of Rihane, Manel, Lemsi and Tej had the low percentage (67, 60, 60, 50\%). Thus, Konouz, Faiz, and Roho cultivars are considered as salt-tolerant cultivars. Instead, Rihane, Manel and Lemsi were moderately salt tolerant. However, Tej cultivar is considered as the most sensitive to salt stress. Indeed, results show that even with a low concentration of $100 \mathrm{mM} \mathrm{NaCl}$, Tej shows a reduction of $50 \%$ of the germination rate compared to control. The obtained results confirm those of previous studies revealing the depressive effect of salt on germination capacity of the others seeds species such as tomato (Allagui et al., 1994), wheat (Ben Naceur et al., 2001), castor (Raghavaiah et al., 2006) and watermelon (Askri et al., 2007).

Our results showed that Barley was a salt-resistant species at radicle breaching stage (Figure 2) which is consistent with other results with the tolerance variability among cultivars (Shannon, 1984; Srivastava \& Jana, 1984).

The decrease in the final germination rate, correspond to an increase in the external osmotic pressure (more negative osmotic pressure) resulted from the increased environment salinity, it disrupts the seed hydration. On the other hand, the high concentration of cations and anions (especially $\mathrm{Na}^{+}$and $\mathrm{Cl}^{-}$) in the environment impede the seed germination by imposing toxicity in seeds (Rajabi \& Postini, 2005; Atak et al., 2006). Germination capacity is nearly $100 \%$ in control medium, for the seven cultivars. It was little affected at low doses of $\mathrm{NaCl}$ $(100 \mathrm{mM}$ and at $150 \mathrm{mM}$ ) but it was reduced significantly at high concentration of $\mathrm{NaCl}$ up to $200 \mathrm{mM}$ for all studied cultivars especially Rihane, Lemsi and Tej where the coleoptile's emergence is completely inhibited (Figure 4B). Mrani-Alaoui et al. (2013) showed that stressed grain germination rate was located below those of control treatment and come up to zero gradually as the $\mathrm{NaCl}$ concentration increases.

In all barley studied cultivars, salinity reduces speed germination without affecting the germination capacity; this depressive effect was already reported in barley by El Mekkaoui (1990). The reduction of germination rate may reflect the embryo sensitivity to osmotic effects of $\mathrm{NaCl}$. The solution of $200 \mathrm{mM} \mathrm{NaCl}$ leads difficult hydration for the embryo, which would be unable to absorb the amount of water needed to start the germination process (Abdelly, 1992). The delay of trigger germination is the time required to set up mechanisms for osmotic adjustment. The decrease in the rate of coleoptile's emergence under high $\mathrm{NaCl}$ concentration was observed in other plants (Bounaqba, 1993) reflecting the slowdown in reserve mobilization to seedling (Prisco et al., 1981). Results indicated that salinity induced delay and decrease the germination percentage through lower water uptake and higher accumulation of $\mathrm{Na}^{+}$and $\mathrm{Cl}^{-}$(Begum et al., 2010). As salinity enhances osmotic pressure leading to a reduction in water absorbance, division and cell differentiation, which negatively affects metabolic and physiological processes. The consequences were a delay of germination processes followed by prolonged seed germination duration (Kang \& Saltveit, 2002).

The study of the germination rates showed that, $\mathrm{NaCl}$ provoked an increase of $\mathrm{T} 50$ or a decrease of the germination speed for all varieties. For controls plants and those exposed to low $\mathrm{NaCl}$ concentrations, the $\mathrm{T} 50$ is little or unaffected for both criteria germination. These results corroborate those of Adjel et al. (2013), who demonstrated for twelve barley genotypes that the germination speed decreased from 16.2 to $8.3 \%$ at $150 \mathrm{mM}$.

These delays of germination by increasing of $\mathrm{NaCl}$ concentrations are due to a problem of hydration seeds as a result of high osmotic potential. Results could be explained also by the high time necessary to trigger mechanisms to adjust osmotic pressure in seeds tissues (Jaouadi et al., 2010; Salehifar et al., 2010).

Germination stress index (GSI) of different barley cultivars was affected by salt stress $(\mathrm{P}<0.05)$ (Figure 6). GSI was significantly reduced by $200 \mathrm{mM} \mathrm{NaCl}$ compared to the control treatment. Our results are consistent with those of Mallek-Maalej et al. (2015).

According to Figures 6 (A) and (B) which shows the differences between GSI studied varieties; the highest value of GSI was registered with Roho, Faiz and Kounouz cultivars. Reduction of germination under salt stress seems to be related to stress intensity and variety (Ben Naceur et al., 2001; Kadri et al., 2009).

\section{Conclusion}

The results reported in this study suggest that barley is supposed as sensitive plant to $\mathrm{NaCl}$ concentration at germination stage. $\mathrm{NaCl}$, at doses up to $200 \mathrm{mM}$, slows the rate of barley germination without affecting their ability to germinate. During the phase of coleoptile's emergence, barley cultivars show greater sensitivity to $\mathrm{NaCl}$ than during radicle breaching, Roho cultivar is distinguished by its ability to emerge at higher doses of $\mathrm{NaCl}(200 \mathrm{mM})$. In absence as in presence of salt, this cultivar has the best germination behaviour. However, Tej and Lemsi cultivars are the most sensitive. Analysis of variance shows highly significant differences in the cultivar and the treatment effect, when we consider the two criteria of germination. According to the tolerance 
index and germination parameters, the salt tolerance in descending order of the studied cultivars is the following: Roho $>$ Faiz $>$ Kounouz $>$ Manel $>$ Rihane $>$ Lemsi $>$ Tej.

In conclusion, the study of barley behaviour, under stress salinity at early stage, by germination parameters and Germination stress tolerance index constitute a good and reliable test to characterize the effect of this contrast on barley cultivars.

\section{References}

Abdelly, C. (1992). Response to nutritional constraints of the main herbaceous vegetation along sebkha (p. 252 , Theses of Specialty in Plant Physiol. Univ. Tunis II).

Adjel1, F., Kadi1, Z., Bouzerzour, H., Benmahammed, A., \& Ben Mhidi, L. (2013). Salt Stress Effects on Seed Germination and Seedling Growth of Barley (Hordeum Vulgare L.) Genotypes. Int. J. Agr. Sustain., 3(2), 223-237.

Allagui, M. B., Andreotti, V. C., \& Cuartero, J. (1994). Determination of selection criteria for tolerance of tomato to salinity. At germination and seedling stage. Ann. INRAT, 67, 45-65.

Ashraf, M. Y., Hussain, F., Akhtar, J., Gul, A., Ross, M., \& Ebert, G. (2008). Effect of different sources and rates of nitrogen and supra optimal level of potassium fertilization on growth, yield and nutrient. Pakistan Journal of Botany, 40(4), 1521-1531.

Askri, H., Rejeb, S., Jebari, H., Nahdi, H., \& Rejeb, M. N. (2007). Effet du chlorure de sodium sur la germination des graines de trois variétés de pastèque (Citrus lanatus L.). Science et Changements Planétaires/Sécheresse, 18(1), 51-55.

Atak, M., Kaya, M. D., Kaya, G., Cikili, Y., \& Ciftci, C. Y. (2006). Effects of NaCl on germination, seedling growth and water uptake of Triticale. Turk J Agri For., 30, 39-47.

Begum, F., Ahmed, I. M., Nessa, A., \& Sultana, W. (2010). The effect of salinity on seed quality of wheat. $J$ Bangladesh Agric. Univ., 8(1), 19-22. http://dx.doi.org/10.3329/jbau.v8i1.6392

Ben Naceur, M., Rahmoune, C., Sdiri, H., Meddahi, M. L., \& Selmi, M. (2001). Effet du stress salin sur la germination, la croissance et la production en grains de quelques variétés maghrébines de blé. Sécheresse, 12(3), 167-74.

Bouaouina, S., Zid, E., \& Hajji, M. (2000). Tolerance to salinity, chlorophyll fluorescence and ion transport in durum wheat (Triticum turgidum L.). Mediterranean Options, Series A: Mediterranean Seminars, 40, 239-243.

Bounaqba, S. (1993). Effects of salt stress on germination and growth of two Varieties of triticale (X, Triticosecale Wittmack) (p. 96). DEA Physiol. Veg. FST, Univ. Tunis II.

Cheikh, M. H., Abdellaoui, R., Kadri, K., Ben Naceur, M., \& Bel Hadj, S. (2008). Evaluation de la tolérance au stress salin de quelques accessions d'orge (Hordum Vulgare L.) cultivées en Tunisie approche physiologique. Science and Technology, 28, 30-37.

Deghais, M., Kouki, M., Gharbi, M. S., \& El-Falah, M. (2007). Varieties of cereals grown in Tunisia. Ministry of Agriculture and Water Resources.

El Mekkaoui, M. (1990). Mechanisms of salt tolerance in durum wheat and barley: Looking for early selection tests (p. 191, PhD. in Agr Sc. Montpellier).

FAO. (2008). Envolée du prix des céréales: Menace sur les pays pauvres.

Gallardo, K., Le Signor, C., Vandekerckhove, J., Thompson, R. D., \& Burstin, J. (2003). Proteomics of Medicago truncatula seed development establishes the time frame of diverse metabolic processes related to reserve accumulation. Plant Physiol., 33, 664-682. http://dx.doi.org/10.1104/pp.103.025254

Jamil, M., Lee, D. B., Jung, K. Y., Ashraf, M., Lee S. C., \& Rha, E. S. (2006). Effect of salt (NaCl) stress on germination and early seedling growth of four vegetables species. The Journal of Central European Agriculture, 7, 273-282.

Jaouadi, W., Hamrouni, L., Souayeh, N., \& Larbi, M. K. (2010). Étude de la germination des graines d'Acacia tortilis sous différentes contraintes abiotiques. Biotechnol. Agron. Soc. Environ., 14(4), 643-652.

Kadri, K., Maalamm, S., Cheikh, H., Benabdalla, A., Rahmoun, C., \& Ben Naceur, M. (2009). Effet du stress salin sur la germination, la croissance et la production en grains de quelques accessions Tunisiennes d'orge (Hordeum Vulguare L.). Science and Technologie C, 29, 72-79. 
Kang, H. M., \& Saltveit, M. E. (2002). Chilling tolerance of maize, cucumber and rice seedlings leaves and roots are differently affected by salicylic acid. Physiol. Plant, 115, 571-576. http://dx.doi.org/10.1034/j.1399-305 4.2002.1150411.x

Karimi, G., Grbanli, M., Heidri, H., Khavarinejad, R. A., \& Assareh, M. H. (2005). The effects of NaCl on growth, water relations, osmolytes and ion content in Kochia prostrate. Bio. Plant, 49, 301-304. http://dx.doi.org/10.1007/s10535-005-1304-y

Khemiri, H., Belguith, H., Jridi, T., Ben El Arbi, M., \& Ben Hamida, J. (2004). Biochemical characterization of an active amylase during germination process of colza seed (Brassica napus L.). Enzymology and metabolism (pp. 146-149). International Congress of Biochemistry, Marrakech, May 3-6, 2004.

Lang, A. (1965). Effects of some internal and external conditions on seed germination. Encyclopedia of Plant Physiology, 15(2), 848-893. http://dx.doi.org/10.1007/978-3-642-50088-6_62

Mallek-Maalej, E., Boulasnem, F., \& Ben Salem, M. (2004). Effet de la salinité sur la germination de graines de céréales cultivées en Tunisie. Cahiers Agriculture 12, 153-6.

Mallek-Maalej, E., Dakhli, R., Abdi, N., Slama, A., \& Ben Salem, M. (2015). Evaluation of the Effect of Salt Stress on Some Physiological and Agronomic Traits in Tunisian Durum Wheat Varieties. Eur. J. Sci. Res., 130(1), 88-100.

Mazher, A. A. M., EL-Quensi, F. E. M., \& Farahat, M. M. (2007). Responses of ornamental plants and woody trees to salinity. World J. Agric. Sci., 3(3), 386-395.

Mrani Alaoui, M., El Jourmi, L., Ouarzane, A., Lazar, S., El Antri1, S., Zahouily, M., \& Hmyene, A. (2013). Effect of salt stress on germination and growth of six Moroccan wheat varieties. J. Mater. Environ. Sci., 4(6), 997-1004.

Munns, R. (2005). Genes and salt stress tolerance: Bringing them together. New Phytol., 167, 645-663. http://dx.doi.org/10.1111/j.1469-8137.2005.01487.x

Munns, R., \& Tester, M. (2008). Mechanisms of salinity tolerance. Annu. Rev. Plant Biol., 59, 651-681. http://dx.doi.org/10.1146/annurev.arplant.59.032607.092911

Parida, A. K., \& Das, A. B. (2005). Salt tolerance and salinity effects on plants: A review. Ecotox. Environ. Safe 60(3), 324-349. http://dx.doi.org/10.1016/j.ecoenv.2004.06.010

Prisco, J. T., \& Filho, E. (1981). Effect of $\mathrm{NaCl}$ salinity on cotyledon starch mobilization during germination of Vigna unguiculata (L.) Walp seeds. Rev. Brasil. Bot., 4, 63-71.

Raghavaiah, C. V., Lavanya, C., Shakti, K., \&Jeevanroyal, T. J. (2006). Screening castor (Ricinus communis) genotypes for salinity tolerance in terms of germination, growth and plant ion composition. Indian J. Agr. Sci., 76(3), 196-199.

Rajabi, R., \& Postini, K. (2005). Effect of $\mathrm{NaCl}$ on thirty cultivars of bread wheat seed germination. Agric. Sci. J., 27(1), 29-45.

Rajaskaran, L. R., Aspinal, D., \& Paleg, L. G. (2000). Physiological mechanism of tolerance of Lycopersicon spp. Exposed to salt stress. Canad. J. plant Sci., 80(1), 151-152. http://dx.doi.org/10.4141/P99-003

Rozema, J. (1975). The influence of salinity, inundation and temperature on the germination of some halophytes and non-halophytes. Oecol. Plant, 10, 341-354.

Salehifar, M., Torang, A., Farzanfar, M., \& Salehifar, M. (2010). Comparison of salinity stress effect on germination and seedling growth in 8 lines genotypes of common bean (Phaseolus vulgaris). $11^{\text {th }}$ Iranian Crop Science Congress.

Shannon, M. C. (1984). Breeding, selection \& the genetics of salt tolerance. In R. C. Staples \& G. H. Toenniessen (Eds.), Salinty tolerance in plants (pp. 231-54). New York: John W iley and Sons.

Slama, A. (1996). Effect of soil water stress on root system development of two durum wheat varieties (p. 87, Master of Science Faculty of Tunis).

Slama, A., Ben Salem, M., Ben Naser, M., \& Zid, E. (2005). Les céréales en Tunisie: Production, effet de la sécheresse et mécanismes de résistance. Sécheresse, 16(3), 225-229.

Slama, F. (2004). La salinité et la production végétale (p. 163). Centre de Publication Universitaire Tunis. 
Smith, S. E., \& Dobrenz, A. K. (1987). Seed age and salt tolerance at germination in Alfalfa. Crop Sci., 87, 1053-1056. http://dx.doi.org/10.2135/cropsci1987.0011183X002700050046x

Srivastava, J. P., \& Jana, S. (1984). Screening wheat and barley germplasm for salt tolerance. In R. C. Staples \& G. H. Toenniessen (Eds.), Salinity tolerance in plants (pp. 273-83). New York: John Wiley and Sons.

Yousofinia, M., Ghassemian, A., Sofalian, O., \& Khomari, S. (2012). Effects of salinity stress on barley (Hordeum vulgare L.) Germination and seedling growth. Intl. J Agri. Crop Sci., 4, 1353-1357.

Zivkovic, S., Devic, M., Filipovic, B., Giba, Z., \& Grubisic, D. (2007). Effect of $\mathrm{NaCl}$ on seed germination in some Centaurium Hill. species (Gentianaceae). Arch. Biol. Sci., 59(3), 227-231. http://dx.doi.org/10.2298/ ABS0703227Z

\section{Copyrights}

Copyright for this article is retained by the author(s), with first publication rights granted to the journal.

This is an open-access article distributed under the terms and conditions of the Creative Commons Attribution license (http://creativecommons.org/licenses/by/4.0/). 